\title{
TEXTBOOK DISCOURSE READABILITY: GENDER, READING INTEREST, AND SOCIO-ECONOMIC STATUS OF STUDENTS WITH POOR READING ABILITY
}

\author{
Sultan*, Muhammad Rapi, Mayong, Suardi \\ Universitas Negeri Makassar, Indonesia \\ *e-mail:sultan@unm.ac.id
}

\begin{abstract}
Textbook discourse readability is primarily determined by three key factors: the text, the writer, and the reader. Textbook discourse readability from the reader aspect especially among students with poor reading ability is rarely studied. Therefore, this study aimed to investigate textbook discourse readability among junior high school students with poor reading ability based on gender, reading interest, and family socio-economic status. A quantitative survey was conducted on 257 respondents from Indonesia. The data were gathered using a questionnaire and a cloze test. The results showed that textbook discourse readability on all investigated variables was categorized into the frustration level. There was a significant difference in textbook discourse readability among students with poor reading ability based on gender, reading interest, and family socio-economic status. Female students, students with high reading interest, students with well-educated mothers, students with parents earning more than seven million rupiahs (equals to USD480/month) were reported to have a higher textbook discourse readability. These findings suggest the importance of considering students' individual characteristics and family socio-economic background in writing a textbook and designing reading instructions in junior high schools.
\end{abstract}

Keywords: poor reader, reading achievement, readability, textbook

\section{KETERBACAAN WACANA BUKU TEKS: GENDER, MINAT BACA, DAN STATUS SOSIAL EKONOMI PADA SISWA BERPRESTASI MEMBACA RENDAH}

\begin{abstract}
Abstrak: Keterbacaan wacana buku teks ditentukan oleh tiga faktor kunci: teks, penulis, dan pembaca. Dari ketiga faktor itu, kajian tingkat keterbacaan buku teks dari aspek pembaca, khususnya pada siswa berprestasi membaca rendah masih sangat terbatas. Penelitian ini bertujuan menginvestigasi keterbacaan wacana buku teks di sekolah menengah pertama berdasarkan variabel gender, minat baca, dan status ekonomi pada siswa berprestasi membaca rendah. Penelitian kuantitatif dengan pendekatan survei diaplikasikan pada 257 sampel di Indonesia. Data dikumpulkan melalui angket dan tes cloze. Hasil penelitian menunjukkan bahwa wacana buku teks berada pada level frustrasi dari semua variabel yang diinvestigasi. Ada perbedaan signifikan tingkat keterbacaan buku teks pada siswa berprestasi membaca rendah berdasarkan variabel gender, minat baca, dan socio-economic status (SES) orang tua. Perempuan, siswa berminat baca tinggi, siswa dengan ibu berlatar belakang pendidikan tinggi, siswa dengan orang tua berpenghasilan lebih dari tujuh juta rupiah (setara USD480/bulan) memiliki tingkat keterbacaan lebih tinggi. Penelitian ini merekomendasikan pentingnya memperhatikan karakteristik siswa dan latar belakang sosial ekonomi keluarga dalam penulisan buku teks dan pembelajaran membaca di sekolah.
\end{abstract}

Kata Kunci: pembaca berkemampuan rendah, prestasi membaca, ketercabaan, buku teks

\section{INTRODUCTION}

The current study was conducted to students with poor reading ability in Indonesia. Performance in International Student Assessment (PISA) and Progress in International Reading Literacy Survey (PIRS) in their survey constantly place Indonesia in the category of countries incompetent in reading (Mullis, Martin, \& Foy
2008; Mullis, Martin, Foy, \& Drucker, 2011; Mullis, Martin, Foy, \& Hooper, 2018; OECD, $2010 ; 2013 ; 2016 ; 2019)$. Compared to other participating countries, Indonesian students continuously rank $10^{\text {th }}$ to last in reading. A study conducted by PISA in 2019 reported that the majority $(60.0 \%)$ of students were at level 1 or 2 in reading and only a small group of students 
(.1\%) secured the fifth or sixth level of reading expertise (OECD, 2019). Therefore, the study on textbook readability among students with poor reading ability becomes an important element to facilitate the process of learning reading in schools since its findings can potentially contribute to the making of policy in textbook writing, selection, publication, and distribution. Research aimed at investigating the readability level of textbook discourse with a specific subject among students with poor reading ability has not been conducted. Therefore, the current study involved four variables of readers in determining the readability level of textbook discourse; they were gender, reading interest, family socioeconomic status, and parents' education.

The level of textbook readability is an indicator of text difficulty and suitability for readers of certain age groups or classes (Wissing, Blignaut, \& van den Berg, 2016). A readability test can assess the feasibility of a textbook as a learning resource and medium for students to develop their reading skills. Readability test is an essential part of reading instructions. It gives an idea of the difficulty level of the text, especially in the context of learning and assessment. Readability is used as a practical consideration in making decisions on adopting suitable materials based on the ability of the target readers (Srisunakrua \& Chumworatayee, 2019).

Textbook readability is affected by various internal or external factors. Kasule (2011) states that text, reader, and writer are the distinguishing factors of readability level. Texts are bound to their linguistic features and structures, readers are attached to their motivation and reading experiences, while writers are entitled to their perspective and way of expressing ideas.

Previous research findings have revealed problems in textbook readability. Trainer (2006) found that the elementary science textbook was difficult to understand by the students. Morales (2019) revealed that textbook readability among the tenth and twelfth graders in Chili was on the same level, but the textbook used for the elevengrade students was more difficult to read. Similar findings were reported by Bansiong (2019) who discovered that textbooks in the Philippines were intentionally written three or four times more difficult than the targeted levels and two to three years older than the users. These research findings indicated that textbooks that are extensively produced and distributed to schools are not necessarily suitable to the readers' needs. As a matter of fact, quality textbooks will affect readers' reading interest and competence. Wang, Zhang, Zhu, Xing, \& Kang (2017) found that there was a correlation between textbook difficulty level and readers' interest in reading the textbook. Textbooks with higher difficulty levels will be less appealing for readers.

The analysis on textbook readability in this study was focused on the readers' aspects. Gender, home literacy environment, family socioeconomic status, reading interest, and ethnic are factors that can influence students' achievement in reading (Hochweber \& Vieluf, 2018; Li, 2016; McGeown, 2015; Mwoma, 2017). Readers' social background can also influence readers' reading competence. However, in the context of textbook readability, this particular aspect is not yet conclusive.

In many studies, gender is reported as a discriminating factor in one's reading ability, motivation, reading choice, strategy, and predictor of reading materials. Unlike women, male students have weak involvement in reading and normally distance themselves from reading activities (Asplund \& Pérez, 2018; Sarroub \& Pernicek, 2016); women like to read for pleasure (Dungworth, Grimshaw, Mcknight, \& Morris, 2004); girls prefer reading fiction books, while boys like factual books better (McGeown, Osborne, Warhurst, Norgate, \& Duncan, 2016). In terms of strategy, men and women apply reading strategies differently (Denton, Wolters, York, Swanson, Kulesz, \& Francis, 2015); compared to male students, female students implement reading strategies more frequently (Bouchamma, Poulin, \& Ruel 2014); women enjoy reading more and read online materials more often than men (Loh, Sun, \& Majid, 2019). Conversely, (Mwoma, 2017) found that boys in Kenya had a slightly better average reading score than girls. Different aspects of reading behavior among men and women that have been proposed can become determinant factors that contribute to the readability levels of textbooks.

Research has also revealed that family socio-economic status (SES), especially parents' income level and education are two factors that can affect students' reading behavior. Findings by Pillay (2017) indicate that the majority of 
students who live in cheap and densely populated housing have poor performance in reading tests. Ergül, Sarıca, Akoğlu, \& Karaman (2017) reported that there was a significant difference among parents with high, medium, and low income in providing literacy environment at home for kindergartners in Turkey. However, family socio-economic status is inversely related to student performance in reading school books, magazines, comics, and digital texts. Children from richer families are unlikely to spend time engaging in reading activities, yet students from lower SES are not greatly engaged in reading fiction books (McGeown et al., 2016).

The results of previous studies showed that parents' education contributed to students' reading behavior. Dolean (2016) found that highly educated mothers made the biggest difference with regard to developing their children's early reading skills. Araújo \& Costa (2015) also discovered the contribution of parents' education to the number of books read by pre-school students in European countries. In this study, parents' income and education were considered as contributing factors of textbook readability among students with poor reading ability. More specifically, parents' educational background in this study referred to mothers' education only. A number of research confirmed that there was a significant correlation between mothers' education, children's cognitive development and reading achievement (Abuya, Oketch, Mutisya, Ngware, \& Ciera, 2013; Abuya, Mutisya, \& Ngware, 2015; Abuya, Mumah, Austrian, Mutisya, \& Kabiru, 2018; Caputi, Lecce, \& Pagnin, 2017; Cui, Liu, \& Zhao, 2019; Schochet, Johnson, \& Ryan, 2020). Even so, the effect of mothers' educational backgrounds on textbook readability level has not been studied.

Reading motivation and interest are the determinant factors contributing to reading behavior. Schaffner, Schiefele, \& Ulferts (2013) found that reading motivation and reading comprehension were significantly correlated. Reading motivation was able to predict adolescence skills to read and summarize texts (McGeown, Duncan, Griffiths, \& Stothard, 2015) and thus contributed significantly to their reading comprehension (Cartwright, Marshall, \& Wray, 2016). However, research by Hamilton, Nolen, \& Abbot (2013) and Law (2008) showed a weak correlation between intrinsic reading motivation and reading comprehension. Likewise, Mucherah, \& Herendeen (2013) discovered a complex relationship between reading motivation and reading achievement. There are contradictory findings on the effect of reading interest on reading achievement, thus, this study aimed to measure textbook readability level among students with poor reading ability.

Despite its long and diverse journey, the analysis on textbook readability is rarely performed among students with poor reading ability and various socio-economic backgrounds. Instead, previous textbook analyses concentrated more on content analysis, such as cultural content in textbooks (Han \& Gu, 2019; Rashidi, Meihami, \& Gritter, 2016; Shah, Elyas, \& Gu, 2019); pedagogical purposes of textbooks (Mena, 2019); ideologies in national identity contained in textbooks (Mena, 2019; Wang, 2016); gender representation in textbooks (Channa, Gilhooly, Channa, \& Manan, 2017); gender, functional and cultural diversity in textbooks (Moreno-Fernández, Moreno-Crespo, Pedrero-García, \& Hunt-Gómez, 2019); social semiotics in textbooks (Alkhateeb, 2019); teacher perceptions on textbook assessment functions (Nasr, Bagheri, Sadighi, \& Rassaei 2019); the quality of textbook content (Asakereh, Yousofi, \& Weisi, 2019; Hojeij, Dillon, Perkins, \& Grey, 2019); and functions and strategies to integrating multicultural values into textbook discourse (Sultan, Haris, \& Anshari, 2020).

Among the three main determinant factors of textbook readability, namely text, reader, and writer, the aspects of text appeared more frequently in previous research. Chen (2016) studied the difficulty level of texts quantitatively based on corpus and algorithm. Green (2019) measured text linguistic complexity on the lexical, phrase, and clause levels. Nandhini \& Balasundaram (2016) analyzed the use of algorithm in optimizing sentence readability. Alharbi (2015) examined the use of vocabulary, grammar, and language skills in textbooks. Unlike the aforementioned studies, the current study was focused on the aspects of reader. Students who were selected as the research samples were those who demonstrated poor performance in reading. Readers' social backgrounds included gender, reading interest, mother's education, and family economic status. The results of this study are expected to provide significant contribution 
to the development of textbooks that are relevant to students' characteristics. In general, the findings of this study can serve as the basis for the empowerment of students' poor reading competence in developing countries. This research aims to explore the readability level among students with poor reading ability based on gender, reading interest, family economic status, and mothers' educational backgrounds.

\section{METHODS}

\section{Participants}

This study employed an exploratory quantitative method to collect and analyze the data. The sample of this study consisted of 257 eight-grade students from junior high schools in the city of Makassar and Soppeng Regency, South Sulawesi province, Indonesia. Participants who came from Makassar represented urban students with higher educational level and higher socio-economic status, while participants who came from Soppeng regency represented the opposite group. The participants were also selected to portray the characteristics of public and private schools' students. The category of parental income was referred to the national average poverty standard set by the Indonesian Central Statistics Agency. The income category was divided into four, i.e. less than two million, between two to four million, four to seven million, and more than seven million (in rupiahs). Parents' education specifically referred to the educational background of the mothers who were grouped according to three main levels of education in Indonesia, namely elementary (elementary \& junior high schools), secondary (high school), and higher education (undergraduate and postgraduate). The characteristics of the samples are shown in Table 1.

Table 1. Demographic Information of Participants $(N=257)$

\begin{tabular}{llcc}
\hline Category & Description & $\boldsymbol{N}$ & $\mathbf{\%}$ \\
\hline Gender & Male & 123 & 47.86 \\
Reading interest & Female & 134 & 52.14 \\
& High & 119 & 46.30 \\
Family income & Low & 138 & 53.70 \\
& $x \leq 2$ millions & 106 & 41.26 \\
& $2<x \leq 4$ millions & 57 & 22.18 \\
\multirow{3}{*}{ Mothers' education } & $4<x \leq 7$ millions & 34 & 13.22 \\
& $x>7$ millions & 60 & 23.34 \\
& Elementary & 93 & 36.19 \\
& Secondary & 103 & 40.08 \\
& Higher education & 61 & 23.73
\end{tabular}

Notes: Standard family income in rupiahs. USD1 equals to IDR14.700.

\section{Instruments and Procedures}

The data were obtained using a questionnaire and a cloze test. The questionnaire was used to collect student demographic data, including gender, parents' income, mothers' education and interest in reading. To maintain research objectivity, the respondents were asked to make their responses anonymous. The response to the questionnaire was given by choosing one of the alternative answers provided. The reading interest questionnaire included the use of free time, the duration of reading time, the types of favorite reading materials, the effort to obtain reading materials, and reading activities (Mansor, Rasul, Rauf, \& Koh, 2013). These questions were developed using Likert scale that consisted of five alternative answers. The questionnaire result was analyzed and used to categorize the students into two categories, students with high reading interest and students with low reading interest.

The initial step to developing the cloze test was to select four pieces of discourse that were able to represent descriptive, argumentative, exposition, and persuasion genres. The discourse was collected from a textbook used by junior 
high school students in Indonesia. The textbook was appointed by the Minister of Education and Culture, Republic of Indonesia as the primary reference of learning in junior high schools. The selection of the discourse was based on the characteristics of junior high school students in Indonesia. Therefore, each text contained at least 250 words.

The texts were transformed into passages through a systematic deletion process according to the cloze test development rule, namely maintaining the first sentence in full in each paragraph (Dennis, 2018). It was intended to help respondents understand the context and guess the omitted words using the remaining vocabulary clues. After that, every fifth word, starting from the second sentence of each paragraph, was systematically stacked. There are variations of word-space in cloze tests used among researchers, but a tighter comparison will increase the reliability of the test (Baghaei, 2011). If the fifth word contained a name, a number, or a preposition, such as "and" or "that," the parable was moved to the sixth syllable and so on. The superimposed part was replaced with a standard sized blank space.
Each of the instruments was accompanied by clear instructions. Data collection was performed by providing an opportunity for the participants to respond to the passages. The respondents completed the questionnaire and cloze test individually in two sessions. During the first session, the respondents were instructed to fill in their demographic information and during the second session, the respondents were given the opportunity to answer the cloze test. The completed passages were evaluated using synonym method where two semantically similar words were considered a correct answer. The use of synonym method, according to Bargate (2012), had no significant effect on the results. Correct answer was scored 1 and incorrect answer was scored 0 .

\section{Data Analysis}

A descriptive analysis with frequency and percentage was used to reveal the readability level of the textbook. This analysis categorized students into one of the categories of textbook readability, that consist of frustration, instructional, and independent. The criteria for each category can be seen in Table 2 .

Table 2. The Criteria for Textbook Readability Level

\begin{tabular}{cll}
\hline Cloze Score (\%) & Category & Description \\
\hline$y \leq 40$ & Frustration & $\begin{array}{l}\text { Language is difficult for readers to cope with } \\
\text { Readers are able to cope with the language, but some } \\
\text { assistance is required }\end{array}$ \\
$\begin{array}{c}\text { Instructional } \\
y>60\end{array}$ & Independent & Readers are able to cope with the language \\
\hline
\end{tabular}

Source: (Bargate, 2012; Rye, 1985)

The difference in the textbook readability level based on gender, reading interest, parental income and education was measured using inferential statistics. $t$-test analysis was performed to investigate the difference in the textbook readability level based on gender and reading interest, while analysis of variance (ANOVA) was run to examine the difference in the textbook readability level based on parental income and education. Scheffe post hoc test was used to measure the significant difference among variables. The inferential statistic analysis were assisted by the IBM SPSS 23 . The significance level determined was .05 (95\%).

\section{FINDINGS AND DISCUSSION Findings Textbook Readability Levels}

The descriptive analysis showed that the textbook discourse was categorized into frustration level to all students on examined variables. Table 3 indicated that $49.81 \%(N=128)$ students were on the frustration level, $22.96 \%(N$ $=59)$ students were on the instructional level, and $27.23 \%(N=70)$ were on the independent level. Therefore, it can be concluded that the textbook was categorized into the frustration level. 
Table 3. Textbook Readability Levels

\begin{tabular}{|c|c|c|c|c|c|c|c|}
\hline \multirow{2}{*}{ Variables } & \multirow{2}{*}{ Sub-variables } & \multicolumn{2}{|c|}{ Independent } & \multicolumn{2}{|c|}{ Instructional } & \multicolumn{2}{|c|}{ Frustration } \\
\hline & & $f$ & $\%$ & $f$ & $\%$ & $f$ & $\%$ \\
\hline \multirow[t]{2}{*}{ Gender } & Male & 24 & 9.33 & 29 & 11.29 & 70 & 27.24 \\
\hline & Female & 46 & 17.90 & 30 & 11.67 & 58 & 22.57 \\
\hline \multirow{2}{*}{ Reading interest } & High & 40 & 15.56 & 26 & 10.12 & 53 & 20.63 \\
\hline & Low & 30 & 11.67 & 33 & 12.84 & 75 & 29.18 \\
\hline \multirow[t]{4}{*}{ Family income } & $x \leq 2$ millions & 37 & 14.40 & 24 & 9.34 & 45 & 17.52 \\
\hline & $2<x \leq 4$ millions & 19 & 7.39 & 8 & 3.12 & 30 & 11.67 \\
\hline & $4<x \leq 7$ millions & 10 & 3.89 & 7 & 2.72 & 17 & 6.61 \\
\hline & $x>7$ millions & 4 & 1.55 & 20 & 7.78 & 36 & 14.01 \\
\hline \multirow[t]{4}{*}{ Mothers' education } & Elementary & 14 & 5.45 & 25 & 9.73 & 54 & 21.01 \\
\hline & Secondary & 37 & 14.41 & 23 & 8.95 & 43 & 16.73 \\
\hline & Higher education & 19 & 7.39 & 11 & 4.28 & 31 & 12.06 \\
\hline & Total & 70 & 27.23 & 59 & 22.96 & 128 & 49.81 \\
\hline
\end{tabular}

Gender Differences on Textbook Readability

Table 4 showed that there was a significant difference in the textbook readability level between male and female students $(t=3.942$; $p=.000)$. Female students reported a higher average score $(M=18.50)$ than male students $(M=14.35)$

Table 4. The Difference in Textbook Readability Based on Gender

\begin{tabular}{lcccccc}
\hline Gender & $\boldsymbol{N}$ & $\boldsymbol{M}$ & $\boldsymbol{S D}$ & $\boldsymbol{S E}$ & $\boldsymbol{t}$ & $\boldsymbol{p}$ \\
\hline Male & 123 & 14.35 & 7.934 & .715 & \multirow{2}{*}{3.942} & .000 \\
Female & 134 & 18.50 & 8.667 & .749 & & \\
\hline
\end{tabular}

\section{Reading Interest Differences on Textbook Readability}

Table 5 showed that there was a significant difference in the textbook readability level between students with low reading interest and students with high reading interest $(t=2.256$; $p=.025)$. Students with high reading interest obtained a higher average score $(M=17.77)$ than students with low reading interest $(M=15.38)$.

Table 5. The Difference in Textbook Readability Based on Student Reading Interest

\begin{tabular}{lccccc}
\hline Reading Interest & $\boldsymbol{N}$ & $\boldsymbol{M}$ & $\boldsymbol{S D}$ & $\boldsymbol{t}$ & $\boldsymbol{p}$ \\
\hline Low reading interest & 138 & 15.38 & 8.121 & 2.256 & .025 \\
High reading interest & 119 & 17.77 & 8.900 & & \\
\hline
\end{tabular}

\section{Mothers' Education Differences on Textbook Readability}

Table 6 indicated a significant difference in the textbook readability level between students whose mothers were highly educated and those whose mothers were poorly educated $(F=5.095$, $p=.007)$. Students whose mothers received education at the elementary level (elementary and junior high school) achieved the lowest average score $(M=14.30)$, while students whose mothers attended university obtained the highest average score $(M=18.04)$. Scheffe post hoc test proved that there was a significant difference in the average scores between students whose mothers graduated from university and students whose mothers graduated from elementary or junior high school students; however, there was no significant difference in the average scores between students whose mothers received education at the elementary level and students whose mothers graduated from high schools. In addition, no significant difference was observed between students whose mothers attended university and students whose mothers graduated from high schools.

Table 6. The Difference in Textbook Readability Based on Mothers' Education

\begin{tabular}{lccccc}
\hline $\begin{array}{l}\text { Mothers' } \\
\text { Education }\end{array}$ & $\boldsymbol{N}$ & $\boldsymbol{M}$ & $\boldsymbol{S D}$ & $\boldsymbol{F}$ & $\boldsymbol{p}$ \\
\hline Elementary & 93 & 14.30 & 7.224 & & \\
Secondary & 103 & 17.20 & 9.033 & 5.095 & .007 \\
Higher-education & 61 & 18.04 & 9.036 & & \\
\hline
\end{tabular}




\section{Family Income Differences on Textbook Readability}

Table 7 delineated a significant difference in the textbook readability level between students who came from low-income families and students who came from high-income families $(F=5.31, p=.001)$. Students whose parents earned less than 2 million rupiahs obtained the lowest average score $(M=12.90)$, while students whose parents made more than 7 million rupiahs achieved the highest score $(M=$ 18.37). Scheffe post hoc test showed that there was a significant difference between students whose parents received less than 2 million rupiahs per month and students whose parents obtained more than 7 million rupiahs per month. However, no significant difference was observed between students whose parents earned less than 2 million rupiahs and students whose parents made 2-4 million rupiahs or between students whose parents obtained less than 2 million rupiahs and students whose parents earned 4-7 million rupiahs or between students whose parents made 2-4 million rupiahs and students whose parents collected 4-7 million rupiahs per month.

Table 7. The Difference in Textbook Readability Based on Family Income

\begin{tabular}{cccccc}
\hline Family Income & $\boldsymbol{N}$ & $\boldsymbol{M}$ & $\boldsymbol{S D}$ & $\boldsymbol{F}$ & $\boldsymbol{p}$ \\
\hline$x \leq 2$ & 106 & 12.90 & 5.348 & & \\
$2<x \leq 4$ & 57 & 16.82 & 9.022 & & \\
$4<x \leq 7$ & 34 & 16.38 & 8.406 & & .001 \\
$x>7$ & 60 & 18.37 & 9.267 & & \\
\hline
\end{tabular}

\section{Discussion}

The results showed that the readability level of textbook discourse reported by students with poor reading ability was in the frustration category. The students in general obtained a low average score in the cloze text. The frustration level of textbook readability was constantly observed in all investigated variables, including gender, reading interest, mothers' educational background, and family income level. In all these categories, the percentage of students who were in the frustration category was higher than those who were in the independent and instructional categories. These results signaled that the textbook, instead of helping to ease the students' learning process, prevented the students from developing their reading competence. Bargate (2012) states that students lose motivation and perform poorly in reading when dealing with texts that contain inappropriate difficulty levels. Quality textbooks are those that are intentionally written at the instructional readability level.

The low textbook readability scores observed in this study are also associated with the students' poor reading ability. Students who have poor performance in reading will face various problems in analyzing the context surrounding the texts, interpreting meaning, as well as utilizing syntactic and semantic elements to comprehend the texts. This finding is similar to those of Ghani, Muslim, \& Zakaria (2020) who proved that low ability students had poor reading performance. Students with poor reading ability will also face difficulty in internalizing their reading comprehension (Francis, Caruana, Hudson, \& McArthur, 2019). This finding has an implication that textbook development should consider the target users' reading competence. The readability level of the textbook intended for the students with poor reading ability needs to be adjusted to the students' reading competence. Clear and explicit distinguishing indicators should be decided for the establishment of textbooks, either for readers with excellent or poor reading ability. Both groups can be categorized through the assignment of different levels that have been adjusted to the students' needs in reading.

The statistical analyses proved that there was a significant difference in the textbook readability level based on gender, reading interest, mothers' education, and family income. In terms of gender, girls demonstrated better reading performance compared to boys. This finding has confirmed the previous research findings suggesting the effect of gender difference on reading performance (Ehrtmann \& Wolter, 2018; Lietz, 2006), yet was opposed to Cekiso (2016) and Mwoma (2017). Higher readability levels reported by women are identified as the result of their reading behavior, motivation, attitude, belief, and strategy (Bouchamma et al., 2014; Denton et al., 2015; Logan \& Johnston, 2009). Previous related research indicates that the status of women as better readers has an influence on the readability of textbooks. Positive attitudes and behavior as well as the implementation of varied reading strategies allows girls to receive more 
exposure. This condition helps the girls better understand the textbook content. On the other hand, lower textbook readability levels obtained by boys have implications for learning to read for students with poor reading achievement. The teacher should pay more attention and give a different treatment for boys so they can be involved more in reading activities.

Furthermore, the results of the analyses showed that there was a significant difference in textbook readability between students with high reading interest and students with low reading interest. Students with high reading interest demonstrated higher textbook readability compared to those who have low interest in reading. This finding suggests that students' reading interest is one of the determining factors of textbook readability. Students' low interest in reading can also be associated with their poor reading skills. This particular finding of this study can be explained based on Schaffner et al. (2013). Students with high reading interest usually exhibit higher reading amount compared to those who have low interest in reading. The accumulation of the students' reading experiences has contributed to their vocabulary range, structure comprehension, knowledge of text, and comprehension of the text's context. These aspects are the modality for the students to understand the text better.

The results of this study are also correlated with the findings of McGeown, Norgate, \& Warhurst (2012) who unveiled the relationship between reading motivation and reading skills on very poor readers and very good readers. Students with poor reading skills and low reading interest result must struggle to understand a text. On the other hand, motivation possessed by the students with high reading interest has encouraged them to comprehend the text better. Similarly, Cartwright et al. (2016) state that motivation contributes to reading comprehension. The results of this study are beneficial for teachers in designing reading instructions that can stimulate student reading interest, especially for those who have low reading motivation so that they can enhance their reading comprehension and improve their achievement in reading.

Moreover, a significant difference was observed in textbook readability based on mothers' education. Students with highlyeducated mothers reported higher textbook readability levels compared to those whose mothers only attended elementary and secondary schools; the higher mothers' education, the higher textbook readability level. Thus, it can be interpreted that one' education has a significant effect on textbook readability. This particular finding of this study can be explained based on Husain, Choo, \& Singh (2011) who discovered the correlation between mothers' education and home literacy environment. Mothers with relatively higher education feel that their children can perform better in schools if they play an active role in developing their literacy competence. Therefore, parents' literacy awareness, the creation of a conducive literacy environment at home, and guided home literacy activities can increase textbook readability among children.

The significant difference in textbook readability based on parents' education is in line with Myrberg \& Rosén (2008) who found that parents' education was key to children's achievement in reading in various countries. Highly educated parents possess the ability to prepare early literacy activities and design a literacy environment for their children at home. Eventually, these literacy activities will impact on the children's reading ability, including textbook readability. This finding is also supported by those of Malin, Cabrera, \& Rowe (2014) who discovered that parents' education was a predictor of children's receptive vocabulary skill. Textbook readability involves the aspect of students' vocabulary mastery. Parents who attend higher education will better understand the importance of providing reading environment at home to support their children's reading ability and textbook readability.

The findings of this study also suggest a significant difference in textbook readability based on students' family income. Students with high economic status achieved higher scores in textbook readability compared to students with low family income. Family income is directly proportional to the level of textbook readability among students. Likewise, Husain et al. (2011) proved that there was a positive correlation between family income and children's reading activity. Parents with high earnings believe that their children can learn from other resources besides story books. Findings by Liu, Georgiou, \& Manolitsis (2018) also reveal that family 
income is the predictor of the availability of reading resources at home. Parents who can make money better are able to provide their children with sufficient reading resources at home. This belief and availability of reading resources have a significant impact on children in terms of textbook readability. This factor is also believed as the discriminant factor in textbook readability based on family income.

In conclusion, the findings of this study suggest that there is a significant difference in textbook readability based on gender, reading interest, mothers' education, and family income. Textbook writers and publishers need to consider the social characteristics of the target users. The analyses performed in this study categorized students with poor reading ability into the frustration level in understanding textbook discourse; in other words, the students will face various difficulties during the learning process. Textbooks that are disseminated into schools need to be be adjusted to the students' reading ability. Textbook authors or publishers need to conduct a tryout before distributing the textbooks to the target users. In terms of reading instructions in schools, the results of this study need to be responded by teachers by providing students with guided reading activities and reading strategies that are appropriate for their gender, reading interest, and socio-economic status.

\section{CONCLUSION}

The results of this study showed the category of frustration on all variables studied. Students with poor reading ability have difficulty in reading textbook discourse. It can be concluded that the low textbook readability levels resulted from the characteristics of the students who possessed poor reading ability. The frustration category indicates that the textbook has not corresponded to the level of student ability. Therefore, textbooks need be written by considering students' reading competence and achievement. For this reason, this study recommends the need for clear and decisive indicators in textbook writing based on readers' reading ability (high or low ability).

Findings from this study also emphasize the impact of students' social backgrounds on textbook readability. Gender, reading interest, mothers' education, and family income are differentiating variables in textbook readability. The current study provides an insight for teachers in designing textbooks that are suitable with students' characteristics. This study also suggests the importance of developing textbooks specifically for students with poor reading ability. Teachers need to refine their skills in designing reading instructions and preparing reading resources that are relevant to student gender, reading interest, and socio-economic status.

The limitation of this study lies on the sample of the textbook which was only focused on the Indonesian language textbook. Future researchers can improve the findings by conducting an analysis on interdisciplinary textbooks so that textbook readability can mapped thoroughly. This study only used a cloze test as the instrument to measure textbook readability; therefore, future research can combine several types of readability tests to see the consistency of the results. Different characteristics of the text in terms of structure and genre also need to be considered further in analyses. Texts have different linguistic structures and characteristics, so they have the potential to impact on the textbook readability levels.

\section{REFERENCES}

Abuya, B. A., Mumah, J., Austrian, K., Mutisya, M., \& Kabiru, C. (2018). Mothers' education and girls' Achievement in Kibera: The link with self-efficacy. SAGE Open, 8(1), 1-10. https://doi. org/10.1177/2158244018765608.

Abuya, B. A., Mutisya, M., \& Ngware, M. (2015). Association between mothers' education and grade six children numeracy and literacy in Kenya. Education 3-13, 43(6), 653-665. https://doi.org/10.1080/030042 79.2013.855250.

Abuya, B. A., Oketch, M., Mutisya, M., Ngware, M., \& Ciera, J. (2013). Influence of mothers' education on children's maths achievement in Kenya. Education 3-13, 41(6), 633-646. https://doi.org/10.1080/0 3004279.2011 .631562 .

Alharbi, A. (2015). A descriptive-evaluative study of a Saudi EFL textbook series. Cogent Education, 2(1), 1-26. https://doi. org/10.1080/2331186X.2015.1079946. 
Alkhateeb, M.A. (2019). Semiotic characteristics of the $9^{\text {th }}$ grade math textbook. Pedagogika, 136(4), 89-108. https://doi. org/10.15823/p.2019.136.6.

Araújo, L., \& Costa, P. (2015). Home book reading and reading achievement in EU countries: The progress in international reading literacy study 2011 (PIRLS). Educational Research and Evaluation, 21(5-6), 422-438. https://doi.org/10.1080 /13803611.2015.1111803.

Asakereh, A., Yousofi, N., \& Weisi, H. (2019). Critical content analysis of English textbooks used in the Iranian education system: Focusing on ELF features. Issues in Educational Research, 29(4), 10161038. http://www.iier.org.au/iier29/ asakereh.pdf.

Asplund, S.-B., \& Pérez, H. P. (2018). Young working-class men do not read: Or do they? Challenging the dominant discourse of reading. Gender and Education, 30(8), 1048-1064. https://doi.org/10.1080/0954 0253.2017 .1303825 .

Baghaei, P. (2011). Do C-tests with different number of gaps measure the same construct? Theory and Practice in Language Studies, 1(6), 688-693. https:// doi.org/10.4304/tpls.1.6.688-693.

Bansiong, A. J. (2019). Readability, content, and mechanical feature analysis of selected commercial science textbooks intended for third grade filipino learners. Cogent Education, 6(1), 1-22. https://doi.org/10 .1080/2331186X.2019.1706395.

Bargate, K. (2012). The readability of managerial accounting and financial management textbooks. Meditari Accountancy Research, 20(1), 4-20. https://doi. org/10.1108/10222521211234192.

Bouchamma, Y., Poulin, V., \& Ruel, C. (2014). Impact of reading strategy use on girls' and boys' achievement. Reading Psychology, 35(4), 312-331. https://doi.org/10.1080/0 2702711.2012.724043.

Caputi, M., Lecce, S., \& Pagnin, A. (2017). The role of mother-child and teacher-child relationship on academic achievement. European Journal of Developmental Psychology, 14(2), 141-158. https://doi. org/10.1080/17405629.2016.1173538.

Cartwright, K. B., Marshall, T. R., \& Wray, E. (2016). A longitudinal study of the role of reading motivation in primary students' reading comprehension: Implications for a less simple view of reading. Reading Psychology, 37(1), 55-91. https://doi.org/ 10.1080/02702711.2014.991481.

Cekiso, M. (2016). Gender differences in the reading comprehension of grade three rural learners in South Africa. International Journal of Educational Sciences, 13(2), 247-254. https://doi.org/10.1080/097511 22.2016.11890458.

Channa, L. A., Gilhooly, D., Channa, A. R., \& Manan, S. A. (2017). Teaching English or producing docility? Foucauldian analysis of Pakistani state-mandated English textbooks. Cogent Education, 4(1), 1-17. https://doi.org/10.1080/23311 86X.2017.1283101.

Chen,A.C.-H. (2016). A critical evaluation of text difficulty development in ELT textbook series: A corpus-based approach using variability neighbor clustering. System, 58, 64-81. https://doi.org/10.1016/j. system.2016.03.011.

Cui, Y., Liu, H., \& Zhao, L. (2019). Mother's education and child development: Evidence from the compulsory school reform in China. Journal of Comparative Economics, 47(3), 669-692. https://doi. org/10.1016/j.jce.2019.04.001.

Dennis, M. O. (2018). A comparison of readability and understandability in second language acquisition textbooks for pre-service EFL teachers. The Journal of AsiaTEFL, 15(3), 750-765. https://doi. org/10.18823/asiatefl.2018.15.3.12.750.

Denton, C. A., Wolters, C. A., York, M. J., Swanson, E., Kulesz, P. A., \& Francis, D. J. (2015). Adolescents' use of reading comprehension strategies: Differences 
related to reading proficiency, grade level, and gender. Learning and Individual Differences, 37, 81-95. https://doi. org/10.1016/j.lindif.2014.11.016.

Dolean, D. (2016). Enhancing the pre-literacy skills of roma children: The role of socio-economic status and classroom interventions in the development of phonemic awareness. The New Educational Review, 45(3), 39-51. https:// doi.org/10.15804/tner.2016.45.3.04.

Dungworth, N., Grimshaw, S., Mcknight, C., \& Morris, A. (2004). Reading for pleasure?: A summary of the findings from a survey of the reading habits of year 5 pupils. New Review of Children's Literature and Librarianship, 10(2), 169-188. https:// doi.org/10.1080/1361454042000312284.

Ehrtmann, L., \& Wolter, I. (2018). The impact of students' gender-role orientation on competence development in mathematics and reading in secondary school. Learning and Individual Differences, 61, 256-264. https://doi.org/10.1016/j. lindif.2018.01.004.

Ergül, C., Sarıca, A. D., Akoğlu, G., \& Karaman, G. (2017). The home literacy environments of turkish kindergarteners: Does SES make a difference? International Journal of Instruction, 10(01), 187-202. https:// doi.org/10.12973/iji.2017.10112a.

Ghani, A. A., Muslim, N. H., \& Zakaria, M. N. (2020). The effects of gender and academic achievement on reading fluency among year 2 Malaysian school children. International Journal of Pediatric Otorhinolaryngology, 132, 109907. https://doi.org/10.1016/j. ijporl.2020.109907.

Francis, D. A., Caruana, N., Hudson, J. L., \& McArthur, G. M. (2019). The association between poor reading and internalising problems: A systematic review and metaanalysis. Clinical Psychology Review, 67, 45-60. https://doi.org/10.1016/j. cpr.2018.09.002.

Green, C. (2019). A multilevel description of textbook linguistic complexity across disciplines: Leveraging NLP to support disciplinary literacy. Linguistics and Education, 53, 1-11. https://doi. org/10.1016/j.linged.2019.100748.

Hamilton, E. W., Nolen, S. B., \& Abbot, R. D. (2013). Developing measures of motivational orientation to read and write: A longitudinal study. Learning and Individual Differences, 28, 151-166. https://doi.org/10.1016/j. lindif.2013.04.007.

Han, J., \& Gu, M. M. (2019). How is culture represented in textbooks? - "Marriage" in Korean language textbooks used in English-speaking countries. Cogent Education, 6(1), 1-15. https://doi.org/10.1 080/2331186X.2019.1632015.

Hochweber, J., \& Vieluf, S. (2018). Gender differences in reading achievement and enjoyment of reading: The role of perceived teaching quality. The Journal of Educational Research, 111(3), 268-283. https://doi.org/10.1080/00220671.2016.1 253536.

Hojeij, Z., Dillon, A. M., Perkins, A., \& Grey, I. (2019). Selecting high quality dual language texts for young children in multicultural contexts: A UAE case. Issues in Educational Research, 29(4), 1201-1222. http://www.iier.org.au/iier. html.

Husain, F. M., Choo, J. C. S., \& Singh, M. K. M. (2011). Malaysian mothers' beliefs in developing emergent literacy through reading. Procedia-Social and Behavioral Sciences, 29, 846-855. https://doi. org/10.1016/j.sbspro.2011.11.313.

Kasule, D. (2011). Textbook readability and ESL learners. Reading \& Writing, 2(1), 63-76. https://doi.org/10.4102/rw.v2i1.13.

Law, Y-K. (2008). The relationship between extrinsic motivation, home literacy, classroom instructional practices, and reading proficiency in second-grade Chinese children. Research in Education, 80(1), 37-51. https://doi.org/10.7227/ 
RIE.80.4.

Li, H. (2016). How is formative assessment related to students' reading achievement? Findings from PISA 2009. Assessment in Education: Principles, Policy \& Practice, 23(4), 473-494. https://doi.org/10.1080/0 969594X.2016.1139543.

Lietz, P. (2006). A meta-analysis of gender differences in reading achievement at the secondary school level. Studies in Educational Evaluation, 32(4), 317-344. https://doi.org/10.1016/j. stueduc.2006.10.002.

Liu, C., Georgiou, G. K., \& Manolitsis, G. (2018). Modeling the relationships of parents' expectations, family's SES, and home literacy environment with emergent literacy skills and word reading in Chinese. Early Childhood Research Quarterly, 43, 1-10. https://doi.org/10.1016/j. ecresq.2017.11.001.

Logan, S., \& Johnston, R. (2009). Gender differences in reading ability and attitudes: Examining where these differences lie. Journal of Research in Reading, 32(2), 199-214. https://doi.org/10.1111/j.14679817.2008.01389.x.

Loh, C. E., Sun, B., \& Majid, S. (2019). Do girls read differently from boys? Adolescents and their gendered reading habits and preferences. English in Education, 54(2), 174-190. https://doi.org/10.1080/0425049 4.2019.1610328.

Malin, J. L., Cabrera, N. J., \& Rowe, M. L. (2014). Low-income minority mothers' and fathers' reading and children's interest: Longitudinal contributions to children's receptive vocabulary skills. Early Childhood Research Quarterly, 29(4), 425-432. https://doi.org/10.1016/j. ecresq.2014.04.010.

Mansor, A. N., Rasul, M. S., Rauf, R. A. A., \& Koh, B. L. (2013). Developing and sustaining reading habit among teenagers. The Asia-Pacific Education Researcher, 22(4), 357-365. https://doi.org/10.1007/ s40299-012-0017-1.
McGeown, S. P. (2015). Sex or gender identity? Understanding children's reading choices and motivation: Gender identity and reading choices. Journal of Research in Reading, 38(1), 35-46. https://doi. org/10.1111/j.1467-9817.2012.01546.x.

McGeown, S. P., Duncan, L. G., Griffiths, Y. M., \& Stothard, S. E. (2015). Exploring the relationship between adolescent's reading skills, reading motivation and reading habits. Reading and Writing, 28(4), 545569. https://doi.org/10.1007/s11145-0149537-9.

McGeown, S. P., Norgate, R., \& Warhurst, A. (2012). Exploring intrinsic and extrinsic reading motivation among very good and very poor readers. Educational Research, 54(3), 309-322. https://doi.org/10.1080/0 0131881.2012.710089.

McGeown, S. P., Osborne, C., Warhurst, A., Norgate, R., \& Duncan, L. G. (2016). Understanding children's reading activities: Reading motivation, skill and child characteristics as predictors: Children's Reading Activities. Journal of Research in Reading, 39(1), 109-125. https://doi.org/10.1111/1467-9817.12060.

Mena, N. P. (2019). Teaching violence, drug trafficking and armed conflict in Colombian schools: Are history textbooks deficient? Issues in Education Research, 29(3), 899-922. http://www.iier.org.au/ iier29/palacios.pdf.

Morales, B. C. (2019). Readability and types of questions in Chilean EFL high school textbooks. TESOL Journal, 11(2), 1-15. https://doi.org/10.1002/tesj.498.

Moreno-Fernández, O., Moreno-Crespo, P., Pedrero-García, E., \& Hunt-Gómez, C. I. (2019). Spanish first cycle primary school textbooks' graphic representations. a study on gender, culture and functional diversity. Pedagogika, 136(4), 67-88. https://doi.org/10.15823/p.2019.136.5.

Mucherah, W., \& Herendeen, A. (2013). Motivation for reading and upper primary school students' academic achievement in 
reading in Kenya. Reading Psychology, 34(6), 569-593. https://doi.org/10.1080/0 2702711.2012.664249.

Mullis, I. V. S., Martin, M. O., \& Foy, P. (Ed.). (2008). TIMSS 2007 international mathematics report: Findings form IEA's trend in international mathematics and science study at the fourth and eighth grades. Chestnut Hill, MA: TIMSS \& PIRLS International Study Center, Boston College.

Mullis, I. V. S., Martin, M. O., Foy, P., \& Drucker, K. T. (Eds.). (2011). PIRLS 2011 international results in reading. Chestnut Hill, MA: TIMSS \& PIRLS International Study Center, Boston College.

Mullis, I. V. S., Martin, M. O., Foy, P., \& Hooper, M. (2018). PIRLS 2016 International Results in Reading. Chestnut Hill, MA: TIMSS \& PIRLS International Study Center, Boston College.

Mwoma, T. (2017). Children's reading ability in early primary schooling: Challenges for a Kenyan rural community. Issues in Educational Research, 27(2), 347-364. http://www.iier.org.au/iier27/mwoma.pdf.

Myrberg, E., \& Rosén, M. (2008). A path model withmediating factors of parents'education on students' reading achievement in seven countries. Educational Research and Evaluation, 14(6), 507-520. https://doi. org/10.1080/13803610802576742.

Nandhini, K., \& Balasundaram, S. R. (2016). Improving readability through individualized summary extraction, using interactive genetic algorithm. Applied Artificial Intelligence, 30(7), 635-661. https://doi.org/10.1080/08839514.2016.1 196570.

Nasr, M., Bagheri, M. S., Sadighi, F., \& Rassaei, E. (2019). Iranian EFL teachers' assessment for learning practices and barriers: Do textbooks taught and teaching context matter? Cogent Arts \& Humanities, 6(1), 1-28. https://doi.org/10.1080/23311983.2 019.1646691 .
OECD. (2010). PISA 2009 results: What students know and can do: Student performance in Reading, Mathematics and Science (Volume I). Paris: Author. https://doi. org/10.1787/9789264091450-en.

OECD. (2013). PISA 2012 results: What students know and can do - Student performance in Mathematics, Reading and Science (Volume I). Paris: Author. https://doi. org/10.1787/9789264201118-en.

OECD. (2016). PISA 2015 results (Volume I): Excellence and equity in education. Paris: Author. https://doi. org/10.1787/9789264266490-en.

OECD. (2019). PISA 2018 results (Volume I): What students know and can do. Paris: Author. https://doi.org/10.1787/5f07c754en.

Pillay, J. (2017). The relationship between housing and children's literacy achievement: Implications for supporting vulnerable children. South African Journal of Education, 37(2), 1-10. https:// doi.org/10.15700/saje.v37n2a1268.

Rashidi, N., Meihami, H., \& Gritter, K. (2016). Hidden curriculum: An analysis of cultural content of the ELT textbooks in inner, outer, and expanding circle countries. Cogent Education, 3(1), 1-17. https://doi. org/10.1080/2331186X.2016.1212455.

Rye, J. (1985). Cloze procedure and the teaching of reading. Oxford, UK: Heinemann Educational Books.

Sarroub, L. K., \& Pernicek, T. (2016). Boys, books, and boredom: A case of three high school boys and their encounters with literacy. Reading \& Writing Quarterly, 32(1), 27-55. https://doi.org/10.1080/105 73569.2013 .859052 .

Schaffner, E., Schiefele, U., \& Ulferts, H. (2013). Reading amount as a mediator of the effects of intrinsic and extrinsic reading motivation on reading comprehension. Reading Research Quarterly, 48(4), 369385. https://doi.org/10.1002/rrq.52. 
Schochet, O. N., Johnson, A. D., \& Ryan, R. M. (2020). The relationship between increases in low-income mothers' education and children's early outcomes: Variation by developmental stage and domain. Children and Youth Services Review, 109, 1-17. https://doi.org/10.1016/j. childyouth.2019.104705.

Shah, M. A., Elyas, T., \& Gu, M. M. (2019). TESOL at the crossroads: Representation of source cultures in TESOL textbooks. Cogent Education, 6(1), 1-19. https://doi. org/10.1080/2331186X.2019.1643524.

Srisunakrua, T., \& Chumworatayee, T. (2019). Readability of reading passages in english textbooks and the thai national education English test: A comparative study. Arab World English Journal, 10(2), 257-269. https://doi.org/10.24093/awej/ vol10no2.20.

Sultan, Haris, H., \& Anshari. (2020). Functions and strategies to the integration of multicultural values in textbook discourse for elementary school students. Lingua Cultura, 14(1), 13-19. https://doi. org/10.21512/lc.v14i1.6219.
Trainer, R. (2006). A readability analysis of elementary level science textbook (Doctoral Dissertation, Florida Atlantic University]. https://ui.adsabs.harvard. edu/abs/2006PhDT........51T/abstract.

Wang, D. (2016). Learning or becoming: Ideology and national identity in textbooks for international learners of Chinese. Cogent Education, 3(1), 1-16. https://doi. org/10.1080/2331186X.2016.1140361.

Wang, X., Zhang, X.-Y., Zhu, R.-F., Xing, A.-H., \& Kang, Z.-F. (2017). An investigation on compiling opinions on and suggestions for a biochemistry textbook from nursing undergraduates. Chinese Nursing Research, 4(3), 141-145. https://doi. org/10.1016/j.cnre.2017.04.003.

Wissing, G.-J., Blignaut, A. S., \& van den Berg, K. (2016). Using readability, comprehensibility and lexical coverage to evaluate the suitability of an introductory accountancy textbook to its readership. Stellenbosch Papers In Linguistics, 46(2), 155-180. https://doi.org/10.5774/46-0205. 